\title{
Kissing Parathyroid Glands: Can be Mistaken for a Single Bilobed Gland
}

\author{
Navendu Mohan ${ }^{1}$, Abhishek Singh ${ }^{2}$, Sudhanshu Tiwari ${ }^{3}$, Azim Anwar $^{4}$, Roma Pradhan ${ }^{5}$
}

\begin{abstract}
Keywords: Hyperparathyroidism, Kissing parathyroid, Parathyroid adenoma.
\end{abstract} World Journal of Endocrine Surgery (2020): 10.5005/jp-journals-10002-1301

A 28-year-young man with h/o recurrent calculi since the age of 23 years was admitted with recurrent vomiting and severe weakness in an another hospital where he was evaluated and was found to

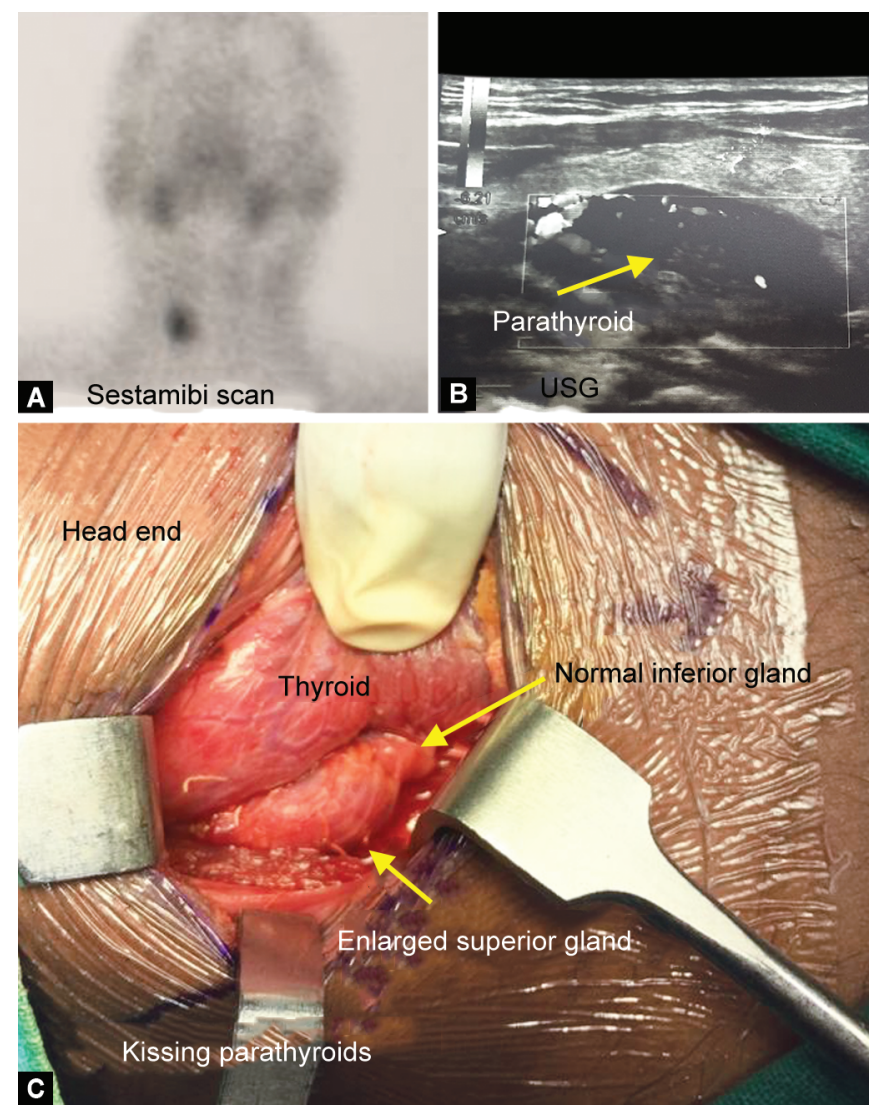

Figs 1 A to C: (A) Sestamibi scan; (B) Ultrasound image; (C) Intraoperative picture showing kissing parathyroid glands
${ }^{1-5}$ Department of Endocrine Surgery, Dr Ram Manohar Lohia Institute of Medical Sciences, Lucknow, Uttar Pradesh, India

Corresponding Author: Roma Pradhan, Department of Endocrine Surgery, Dr Ram Manohar Lohia Institute of Medical Sciences, Lucknow, Uttar Pradesh, India, Phone: +91 9732221166, e-mail: drromapradhan@gmail.com

How to cite this article: Mohan N, Singh A, Tiwari S, et al. Kissing Parathyroid Glands: Can be Mistaken for a Single Bilobed Gland. World $J$ Endoc Surg 2020;12(2):108.

Source of support: Nil

Conflict of interest: None

be having high calcium ( $>15 \mathrm{mg} / \mathrm{dL}$ ) and elevated parathyroid hormone $(946 \mathrm{pg} / \mathrm{mL})$. The patient was managed with IV fluids with which he improved and then was referred to our institute. With high serum calcium and high PTH, a diagnosis of primary hyperparathyroidism was made and localizing investigations were done. High-frequency ultrasound and sestamibi scan were suggestive of right inferior parathyroid adenoma. The patient was taken up for surgery and unilateral exploration was planned with intention to do inferior parathyroidectomy. However, to our surprise, intraoperatively, instead of inferior gland, the right superior gland was found to be enlarged and kissing the normal inferior parathyroid gland. The importance of kissing parathyroid glands lies in the fact that they can be mistaken for a single bilobed gland ${ }^{1}$ especially when the pre-op imaging does not match with intraoperative findings. Hence, the surgeon should be aware of this entity to avoid surgical misadventures! (Fig. 1).

\section{Reference}

1. Liechty RD, Weil 3rd R. Parathyroid anatomy in hyperplasia. Arch Surg 1992;127(7):813-815. discussion 815-6. DOI: 10.1001/ archsurg.1992.01420070073014.

(C) The Author(s). 2020 Open Access This article is distributed under the terms of the Creative Commons Attribution 4.0 International License (https://creativecommons. org/licenses/by-nc/4.0/), which permits unrestricted use, distribution, and non-commercial reproduction in any medium, provided you give appropriate credit to the original author(s) and the source, provide a link to the Creative Commons license, and indicate if changes were made. The Creative Commons Public Domain Dedication waiver (http://creativecommons.org/publicdomain/zero/1.0/) applies to the data made available in this article, unless otherwise stated. 